\title{
Research on Existing Problems and Countermeasures of Supply Chain Financing in Small and Micro Enterprises
}

\author{
HongxingLIU ${ }^{1}$, YuanyuanYU2,a \\ 1 Jiangxi Normal University Science and Technology College, China \\ 2 Jiangxi Normal University Business College, China \\ a jxsdjh@vip.sina.com
} Keywords: Small and medium-sized enterprises, Supply chain financing, Problems
Countermeasures and suggestions

\begin{abstract}
As an important force in the development of national economy, the financing funds of small and medium-sized enterprises are not consistent with the funds that the society is willing to provide, and the gap is large. Under the influence of financing difficulties, the development of small and medium-sized enterprises has been hindered. As a new financing mode, supply chain financing combines banks, enterprises and third party logistics, exerts their respective advantages, forms a win-win model, and provides a new way of thinking for the financing of small and medium-sized enterprises. Based on the analysis of the financing difficulties of SMEs in our country, this paper introduces the new mode of supply chain financing, and puts forward some countermeasures and suggestions for the supply chain financing of small and medium-sized enterprises in China.
\end{abstract}

\section{Introduction}

In China, small and micro enterprises are a powerful driving force for economic development. In the process of development, the credit market has grown rapidly, but the gap between demand and credit supply is very large. The problem of financing difficulties has always existed in the process of enterprise development. Due to the limitations of their own conditions, small and micro enterprises have difficulty in indirect financing through capital markets or direct financing through banks. Supply chain financing is generated as the global economic integration develops. Supply chain financing actually refers to finding a central point in the entire supply chain, and using this as a starting point to radiate outwards and provide financial services to enterprises in the upstream and downstream of the supply chain, so that funds can be better collected. Where it is needed, it can solve the problem of financing difficulties of some enterprises and the imbalance of supply chain.

\section{Analysis of the Advantages of Small and Micro Enterprise Supply Chain Financing}

\subsection{The meaning of supply chain finance}

Tower Group, an internationally renowned financial advisory and consulting firm, defines supply chain financing as follows: Supply chain financing is based on the value of business transactions occurring in the supply chain, designing a range of liquid capital financing and cash flow for suppliers. s solution. The definition of supply chain financing is inseparable from the definition of supply chain. Combined with the concept of using more, the supply chain can be defined as a core enterprise, through the control of information, capital and logistics, raw material suppliers, product manufacturers, As well as the final product related wholesalers and retailers combined into a whole structure. Through the overall development of the upstream and downstream enterprises in the industrial chain where the core enterprises are located, the bank provides a whole package of credit for the core enterprises and upstream and downstream enterprises, and achieves the purpose of marketing the entire supply chain.

\subsection{Advantages of small and micro enterprise supply chain financing}

Supply chain financing is a new concept. At present, based on the enterprise perspective, supply 
chain financing has not yet been defined. Supply chain financing, as a new financing method for small and micro enterprises, solves the problem of financing difficulties for small and micro enterprises, and promotes the rapid development of small and micro enterprises. In the traditional financing model, the upstream and downstream enterprises are treated separately and differentiated, and credited and managed separately. However, due to the small size of the small and micro enterprises in the upstream and downstream, the difficulty and risk of credit are very large. Compared with the traditional financing methods, the supply chain financing model is based on the core enterprises of the supply chain, and regards the upstream and downstream enterprises as a whole, mainly focusing on a financing method for cooperation between core enterprises and small and micro enterprises. The supply chain financing method provides convenient conditions for small and micro enterprise supply chain financing on the basis of traditional financing methods, and the problem of financing difficulties in small and micro enterprises' supply chain has been solved to a certain extent.

\section{Existing problems in small and micro enterprise supply chain financing}

\subsection{Weak awareness of financing}

Today, the supply chain financing model has been implemented in China for some time, but most small and micro enterprises are not skilled in the operation of supply chain financing. This is mainly due to the lack of comprehensive understanding of this emerging model, the lack of awareness of financing through the supply chain, the relationship between small and micro enterprises on the same chain are also very loose, and not actively with the supply chain. The establishment of a good relationship among core enterprises has led to the lack of motivation for core enterprises to integrate them into a complete supply chain management system, which ultimately makes it difficult to form an efficient supply chain financing mechanism. Small and micro enterprises lack the awareness of financing through the supply chain, which makes them unable to follow the pace of the times, and will inevitably be eliminated by the market in the future, lacking the scale of funds needed to compete with other enterprises involved in supply chain financing.

\subsection{Credit risk}

The core enterprises are in a dominant position, integrating logistics, information flow and capital flow. Small and micro enterprises can obtain credit funds, relying on the credit status of core enterprises, strong financial strength and management capabilities. Therefore, small and micro enterprises Survival and development are inseparable from its business conditions. In the supply chain, core enterprises have credit risks, which will inevitably spread to other small and micro enterprises. For example, in the prepayment financing mode, the core enterprise receives the prepayments from the small and micro enterprises, and will deliver the small and micro enterprises. Once the core enterprises fail to deliver the goods on time, the flow of funds in the entire supply chain will be broken. A core enterprise with a higher credit will issue the goods immediately upon receipt of the payment. Choosing a company with higher credit can reduce risk.

\subsection{Risk of depreciation of pledge assets}

The devaluation, liquidity and legality of the pledge directly determine the risk level of the pledge assets. The risk of inventory pledge is mainly reflected in the depreciation of certain stocks, expiration, or rapid shrinkage of value. In addition, there are deficiencies in the management of accounts receivable pledge registration. The Property Law has clarified the legal status of pledge financing for accounts receivable. However, in practice, the regulatory agency has no normative requirements for the preparation of registration content, and there is no standardized registration content. The bank is unable to successfully determine the rights, and even the possibility of repeated registration, affecting the effectiveness of the guarantee. 


\section{Countermeasures for Cracking the Dilemma of Supply Chain Financing in Small and Micro Enterprises}

\subsection{Strengthen supply chain financing awareness}

Supply chain financing, as an emerging financing channel, faces the most obstacles in the operation process from the shackles of traditional ideas. Most domestic small and micro enterprises are accustomed to independent management, and the sense of cooperation is relatively weak. Coupled with the prevalence of localism, cooperation between small and micro enterprises is even more difficult. Therefore, domestic small and micro enterprises must actively exert their own subjective initiative, eliminate the influence of traditional concepts, actively understand the new model of supply chain financing, combine the direction of small and micro enterprise reform, establish a sense of implementing supply chain financing, and deeply understand The implementation of the supply chain financing model is the key to gaining an advantage in market competition.

\subsection{Enhanced credit access management}

In supply chain financing, the credit level of core companies plays a decisive role. When small and micro enterprises use the supply chain for financing, the core enterprises will guarantee the enterprises here. Therefore, their operation status and future development will affect other enterprises in the supply chain, and will also affect the bank's credit and the entire supply. The success or failure of the chain business. Choosing a suitable core company to cooperate is very important for small and micro enterprises to successfully obtain loans. In the process of cooperation, small and micro enterprises should choose core enterprises with good business conditions, high credit rating and huge financial strength to cooperate. For banks, in the supply chain financing business, small and micro enterprises rely on the credit enhancement of core enterprises, although the standards of credit candidates are reduced, but the management of credit enterprises of core enterprises cannot be relaxed. Once a core business has a business crisis, it will spread to other companies in the supply chain.

\subsection{Strengthen asset dynamic management}

In the case of supply chain financing involving goods pledge, financial institutions generally choose a professional third-party logistics warehousing company for supervision. Strengthen cooperation and communication with third-party regulatory agencies, and establish a series of systems such as inspection, inspection, and regular reporting to ensure the true value of the goods. In addition, when selecting small and micro enterprises to pledge assets, they should choose products with broad market demand, relatively stable value, strong liquidity, easy disposal and easy to preserve, such as non-ferrous metals, steel, building materials, petroleum, paper products, grain and oil, Large commodities such as stone, cotton, rubber, and grey cloth are easy to strengthen the value management of the pledge assets.

\section{Summary}

The supply chain financing model gives full play to the advantages of small and micro enterprises as supply chain nodes. It reduces the difficulty of financing through core enterprise guarantees, helps small and micro enterprises to solve financial difficulties, and thus enables the entire supply chain to operate and develop normally. However, traditional financing methods have hidden risks in this financing model. To this end, small and micro enterprises need innovative ways of thinking, actively participate in information sharing in the supply chain, and establish long-term supply chain partnerships. Supply chain financing links supply chain and capital chain closely, takes information flow as accurate connection, gives full play to the effect of logistics and capital flow, optimizes the overall operation of supply chain, and provides assistance for the development of small and micro enterprises. 


\section{Acknowledgement}

This paper is one of the research results of The Research on Innovation of Financing Models of Small and Micro Enterprises in China under Internet Financein The Research Project of the Science and Technology of Jiangxi Provincial Department of Education.

\section{References}

[1] Zhang Xiaoning, Wu Lin. Research on supply chain financing of small and micro enterprises [J]. Northern Economy and Trade, 2018 (08): 130-131.

[2] Jia Nan. Research on Risk Management of Supply Chain Financing in Small and Micro Enterprises[J].Science \& Technology Economic Market, 2018(03):131-132.

[3] Tang Jia. Discussion on Supply Chain Financing Risk of Small and Micro Enterprises and Its Prevention[J]. Market Forum, 2018(04): 52-55.

[4] Zhang Min. Supply Chain Financing, Information Asymmetry and Financing Constraints [J]. Finance and Accounting News, 2018 (09): 121-124.

[5] He Xiangjun. Countermeasures for solving the financing dilemma of small and micro enterprises' supply chain [J]. China Finance, 2018 (05): 70-71.

[6] Li Wei. Analysis of the development of supply chain financing under the Internet financial model [J]. China Business Theory, 2018 (04): 33-34.

[7] Tan Yarong, Liu Wenjing. Financing Development and Innovation Model of Small and Micro Enterprises[J]. Development Research, 2017(05): 141-146.

[8] Ma Huijie. Research on supply chain financing of A company [D]. Inner Mongolia University of Finance and Economics, 2017. 